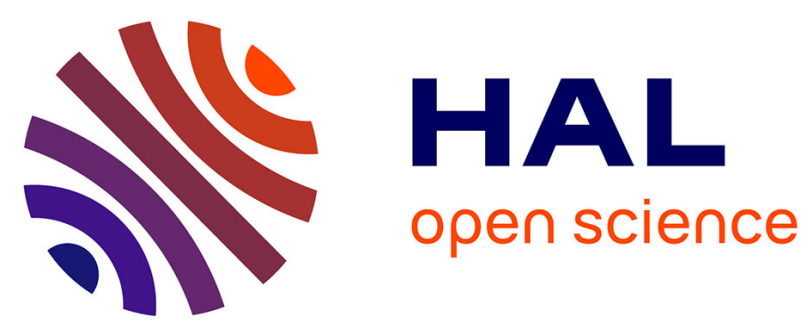

\title{
A new genus and species of fossil scorpion (?Euscorpiidae) from the Early-Middle Eocene of Pesciara (Bolca, Italy)
}

Gabriele Kühl, Wilson R Lourenço

\section{- To cite this version:}

Gabriele Kühl, Wilson R Lourenço. A new genus and species of fossil scorpion (?Euscorpiidae) from the Early-Middle Eocene of Pesciara (Bolca, Italy). Paläontologische Zeitschrift, 2017, 91 (3), pp.283290. 10.1007/s12542-017-0372-6. hal-01755329

\section{HAL Id: hal-01755329 \\ https: / hal.sorbonne-universite.fr/hal-01755329}

Submitted on 30 Mar 2018

HAL is a multi-disciplinary open access archive for the deposit and dissemination of scientific research documents, whether they are published or not. The documents may come from teaching and research institutions in France or abroad, or from public or private research centers.
L'archive ouverte pluridisciplinaire HAL, est destinée au dépôt et à la diffusion de documents scientifiques de niveau recherche, publiés ou non, émanant des établissements d'enseignement et de recherche français ou étrangers, des laboratoires publics ou privés. 


\title{
A new genus and species of fossil scorpion (?Euscorpiidae) from the Early-Middle Eocene of Pesciara (Bolca, Italy)
}

\author{
Gabriele Kühl $^{1} \cdot$ Wilson R. Lourenço ${ }^{2}$
}

\begin{abstract}
Fossil scorpions are among the oldest terrestrial arthropods known from the fossil record. They have a worldwide distribution and a rich fossil record, especially for the Paleozoic. Fossil scorpions from Mesozoic and Cenozoic deposits are usually rare (except in amber-deposits). Here, we describe the only fossil scorpion from the Early to Middle Eocene Pesciara Lagerstätte in Italy. Eoeuscorpius ceratoi gen. et sp. nov. is probably a genus and species within the family Euscorpiidae. This may be the first fossil record of the Euscorpiidae, which are so far only known from four extant genera. Eoeuscorpius ceratoi gen. et sp. nov. was found in the "Lower Part" of the Pesciara Limestone, which is actually dated Late Ypresian stage (between 49.5 and $49.7 \mathrm{Ma}$ ). Besides a possible pseudoscorpion, the here-described fossil scorpion is the second arachnid species known from the Bolca Locality.
\end{abstract}

Keywords Pesciara of Bolca - Euscorpiidae - Lower Eocene $\cdot$ Scorpions

Gabriele Kühl

gkuehl@uni-bonn.de

Wilson R. Lourenço

wilson.lourenco@mnhn.fr

1 Divison of Palaeontology, Steinmann Institute, Nussalle 8, 53115 Bonn, Germany

2 Institut de Systématique, Evolution, Biodiversité (ISYEB), UMR7205-CNRS, MNHN, UPMC, EPHE, Muséum National d'Histoire Naturelle, Sorbonne Universités, CP 53, 57 rue Cuvier, 75005 Paris, France
Kurzfassung Fossile Skorpione gehören zu den ältesten terrestrischen Arthropoden im Fossilbericht. Sie haben eine weltweite Verbreitung und weisen vor allem im Paläozoikum einen guten Fossilbericht auf. Fossile Skorpione aus dem Mesozoikum und Känozoikum sind eher selten (außer in Bernstein-Vorkommen). In dieser Arbeit beschreiben wir einen fossilen Skorpion aus der unter- bis mitteleozänen Pesciara-Lagerstätte in Italien. Eoeuscorpius ceratoi gen. et sp. nov., ist möglicherweise eine Gattung und Art innerhalb der Euscorpiidae. Das könnte der erste fossile Nachweis der Euscorpiidae sein, welche bislang nur durch vier lebende Gattungen bekannt waren. Eoeuscorpius ceratoi gen. et sp. nov., wurde in den „Unteren Ablagerungen “ der Pesciara-Kalksteine gefunden, die gegenwärtig in das späte Ypresium datiert werden (zwischen 49.5 und 49.7 Millionen Jahre). Neben einem möglichen Pseudoscorpion, ist der hier beschriebene fossile Skorpion erst die zweite beschriebene Arachnidenart, die von der Bolca-Lagerstätte bekannt ist.

Schlüsselwörter Pesciara von Monte Bolca . Euscorpiidae · Unteres Eozän · Skorpione

\section{Introduction}

The Bolca Fossil Lagerstätte is a world-famous Lagerstätte for exceptionally preserved fossils from the Eocene. Several hundred plant and animal species have been described from here. Among the animal species, vertebrates (fishes) are dominant and known worldwide. Invertebrates, such as the herein described scorpion, belong to the so-called minor fauna, maybe less famous but no less spectacular. 


\section{Geological and paleobiological background and taphonomy}

The Bolca region is located in the eastern part of the Lessini Mountains, which are within the Southern Alps in Northern Italy (Papazzoni et al. 2014). The limestone developed during the Eocene in two phases of uplift of the Tethys Ocean. It is surrounded by volcanic ash, and the limestone deposits are about $19 \mathrm{~m}$ thick (Tang 2001). The limestone (Lessini Shelf) is especially recognized for a rich fossil record of fishes, which are known throughout the world for the excellent preservation. The Lessini shelf is surrounded by deep marine basins and restricted northwards by terrestrial deposits (Papazzoni et al. 2014).

The fossil scorpion described herein (Cerato 2011; Fig. 4a) was discovered in the Pesciara Fossil-Lagerstätte, which contains marine life forms as well as terrestrial organisms (Guisberti et al. 2014).

The Pesciara Limestone was deposited during the Ypresian stage (Lower Eocene), roughly 49.5 Ma ago. The fossils are found in fine-grained, laminated limestones that were deposited between coarser storm-induced limestone layers (Schwark et al. 2009). The paleoenvironment of the Bolca area is generally regarded as rich in variety. Several ecosystems, reaching from pelagic, as well as shallow marine habitats, and even brackish to fluvial and terrestrial habitats, are evidenced by the deposits. Due to the Eocene climatic conditions, temperatures were tropical to subtropical. The deposits generally prove former advantageous life conditions (Tang 2001), allowing a high degree of biodiversity. However, temporally anoxic and euxinic conditions are assumed by the absence of bottom dwellers (Papazzoni et al. 2014). These events may have let to extinction events that are responsible for the rich fossil fauna.

First, a diverse and abundant fish fauna is represented. The rich fish fauna is interpreted as having been close to coral reefs (Papazzoni et al. 2014). Other vertebrates are represented by two snake specimens, a turtle and several bird remains (for a review, see Carnevale et al. 2014), but also plants are very abundant, with more than 105 macrofaunal genera being described (Wilde et al. 2014).

The fossil fauna and flora are two-dimensionally preserved and frequently fully articulated. Soft part preservation with organs and cuticles is common among the fossils. Even color preservation has been reported. Microbial fabrics may be related to the fossilization of soft tissues (Briggs and McMahon 2016). However, the taphonomic process is actually not well known.

\section{Arthropods from Pesciara of Bolca}

The scorpion described (Fig. 1) here belongs to the so-called minor fauna of the Pesciara-Lagerstätte, which comprises arthropods, polychaete worms, jellyfishes, mollusks, brachiopods and bryozoans. Among arthropods, insects and crustaceans are most abundant (Guisberti et al. 2014). Arachnids, such as the scorpion Eoeuscorpius ceratoi gen. et sp. nov., are only known by two fossils. One is the scorpion described here. The other arachnid is a possible pseudoscorpion from this Lagerstätte (Guisberti et al. 2014).

In general, the order Scorpiones goes back to the mid Silurian of Scotland (see Dunlop 2010 for review). Scorpions from the early Paleozoic generally differ from subsequent groups by a simple coxo-sternal region and the lack of trichobothria, as the latter structures developed as a consequence of terrestrialization. Beginning with the Devonian, a coxapophyses/stomotheca developed in scorpions, which were then very abundant during the Carboniferous (Dunlop 2010). Currently, 136 valid fossil scorpion species have been described, most of them from Paleozoic fossil sites. Mesozoic and Tertiary fossils are comparatively rare, though amber seems to be a good resource for fossil scorpions (Dunlop et al. 2008, 2017; Lourenço 2009, 2014, 2016).

\section{Materials and methods}

The description of the Pesciara scorpion is based on a single specimen, which is the property of Mr. Massimo Cerato in Bolca of Vestenanova and was kindly loaned to us for scientific description. The scorpion, collection number $\mathrm{CMC} 1$, is currently stored at the Museum of the Cerato Family (via San Giovanni Battista, 50-37030 Bolca di Vestenanova-Verona).

The scorpion was $\mathrm{x}$-rayed with a Phoenix vltomelx s Micro Tomograph, but this provided no additional information. The scorpion was also photographed using a Nikon D3x. Details were photographed with a Keyence Digital Microscope. A Leica MZ95 was used to produce fluorescent images.

Image editing was carried out with Adobe Photoshop CS6 in addition to Adobe Illustrator CS6. Measurements were done with the help of ImageJ. Each structure was measured in length and width [mm], except some structures that were regarded as highly fragmentary. Length and width were measured along the middle of each segment (see Table 1). 


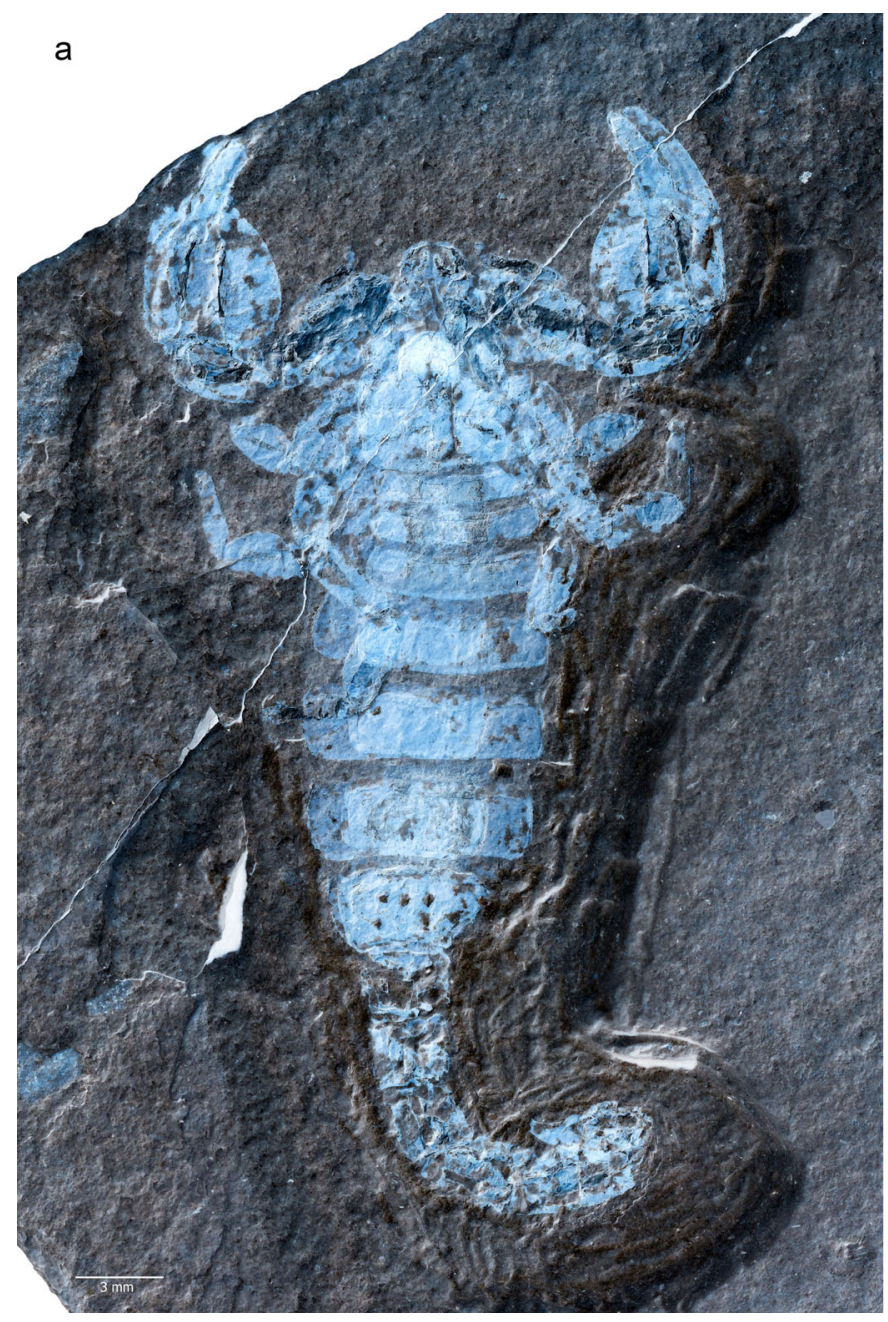

Fig. 1 a Holotype of Eoeuscorpius ceratoi gen. et sp. nov.; the color of the photography is inverted. b Line drawing of the holotype; dashed lines of the trunk and leg indicate indistinct segment (legs) respectively dorsal sternite margins. Densely dashed lines beside and

\section{Systematic paleontology}

Phylum Arthropoda von Siebold, 1848

Class Arachnida Lamarck, 1801

Order Scorpionida Koch, 1837

Family ?Euscorpiidae Laurie, 1896

Genus Eoeuscorpius gen. nov.

Diagnosis of the genus. Scorpion of small size with a total length of $38 \mathrm{~mm}$. General morphology very similar to that of most extant species of the genus Euscorpius Thorell, 1876; however, both body and pedipalps are more bulky and less flattened. Carapace with a strong anterior emargination. Trichobothrial pattern, most certainly of the type $\mathrm{C}$ (Vachon 1974); a number of bothria can be observed: 3 on femur, internal, dorsal and external, 1 dorsal $d_{1}, 1$ internal and a few external on patella; the internal is partially displaced; $4-6$ on dorso-external aspect of chela hand and 5 on chela fixed finger. b

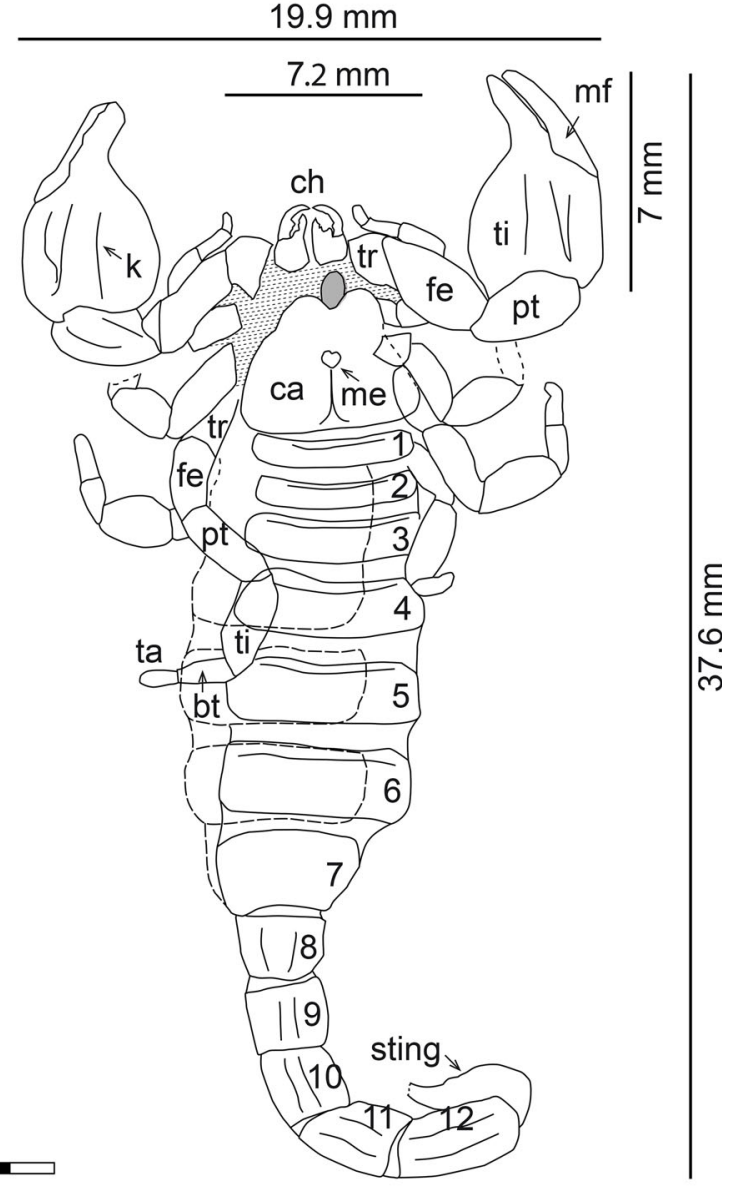

above the carapace indicate an indistinguishable region. $b t$ basitarsus, ca carapace, $c h$ chelicerae, $f e$ femur, $k$ keels, me median eyes, $m f$ moveable finger, $p t$ patella, $t a$ tarsus, $t i$ tibia, $t r$ trochanter. Scale $3 \mathrm{~mm}$

Etymology. The generic name refers to the geological position of the new genus within the Eocene, which is intermediate in relation to elements of the family Palaeoeuscorpiidae Lourenço, 2003 and the extant genus Euscorpius (Lourenço 2003).

Type species. E. ceratoi gen. et sp. nov., from the "Lower Part" of Pesciara Limestone, Early Eocene, Ypresian stage.

Eoeuscorpius ceratoi gen. et sp. nov.

Figure 1a, b.

Material. Holotype, CMC1 (Museum of the Cerato family, Verona).

Diagnosis of the species. As for the genus.

Etymology. The name honors Mr. Massimo Cerato, Bolca of Vestenanova, Italy, who allowed us to study the specimen. Description. The scorpion is exposed from its dorsal side, nearly completely preserved and in an excellent state of 


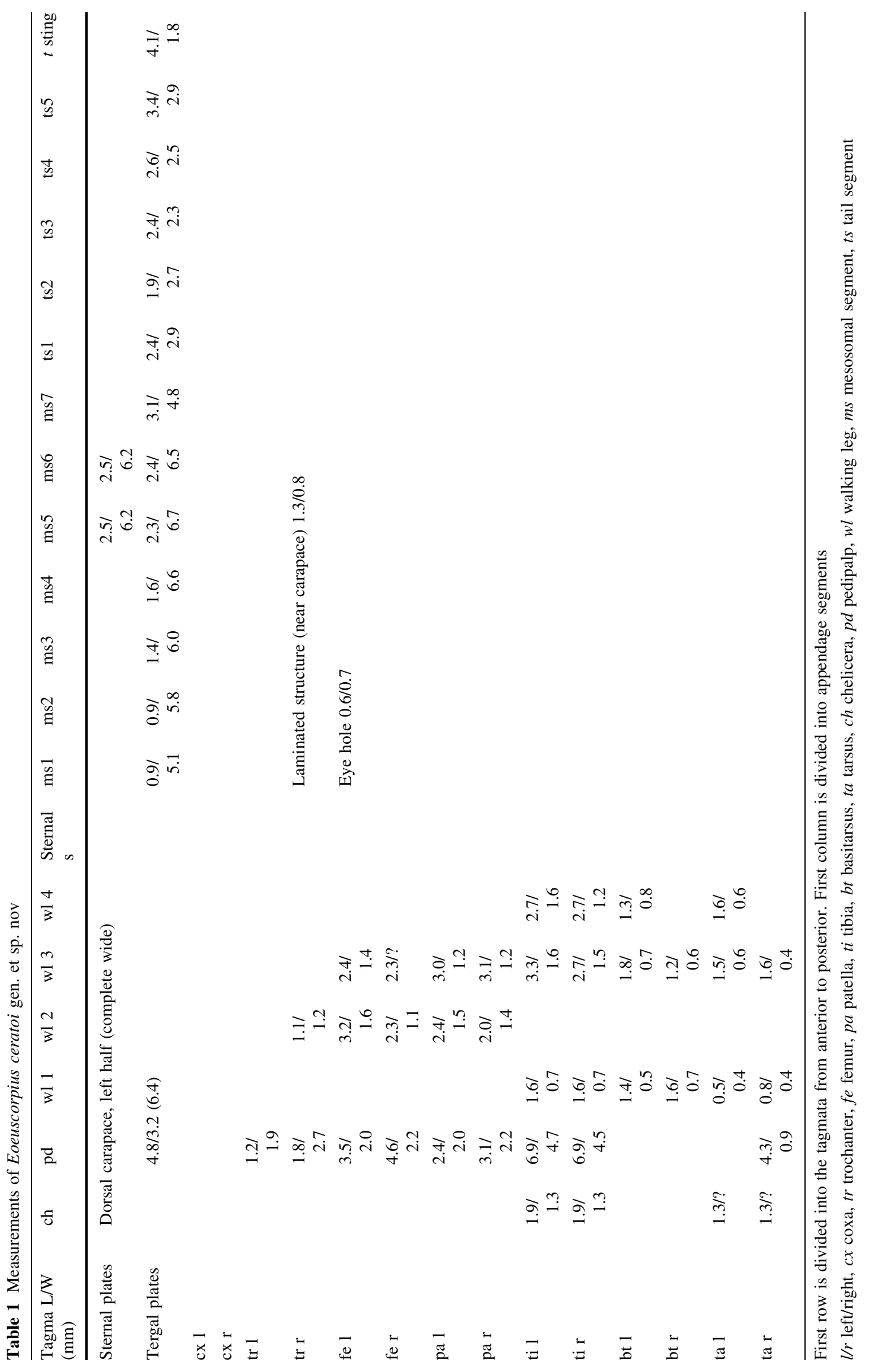


preservation (Fig. 1a), although the distal segments of the walking legs are not well preserved. The cuticle has a brownish coloration and therefore optically stands out against the paler sediment. The cuticle surface is not completely preserved, as smaller areas of usually less than $1 \mathrm{~mm}$ are missing. The cuticle surface of the mesosomal tergites is to some extent transparent, allowing a view to the ventral cuticle. The median eyes are not preserved. In that area the sediment matrix is exposed, indicating the former position of the eyes and eye tubercle. The right carapace half is incomplete but can be reconstructed from the left half. On the cuticle surface, especially of the pedipalps, numerous insertion points of bothria and setae are preserved (Fig. 2a, b).

The body of the fossil scorpion measures ca. $38 \mathrm{~mm}$ in length and ca. $20 \mathrm{~mm}$ in width (Fig. 1b). Chelicerae are ca. $2 \mathrm{~mm}$ long and $1.3 \mathrm{~mm}$ wide. With a width of $4.6 \mathrm{~mm}$ and a length of ca. $7 \mathrm{~mm}$, the chela-bearing segments of the pedipalps are very strong, and they are the optically

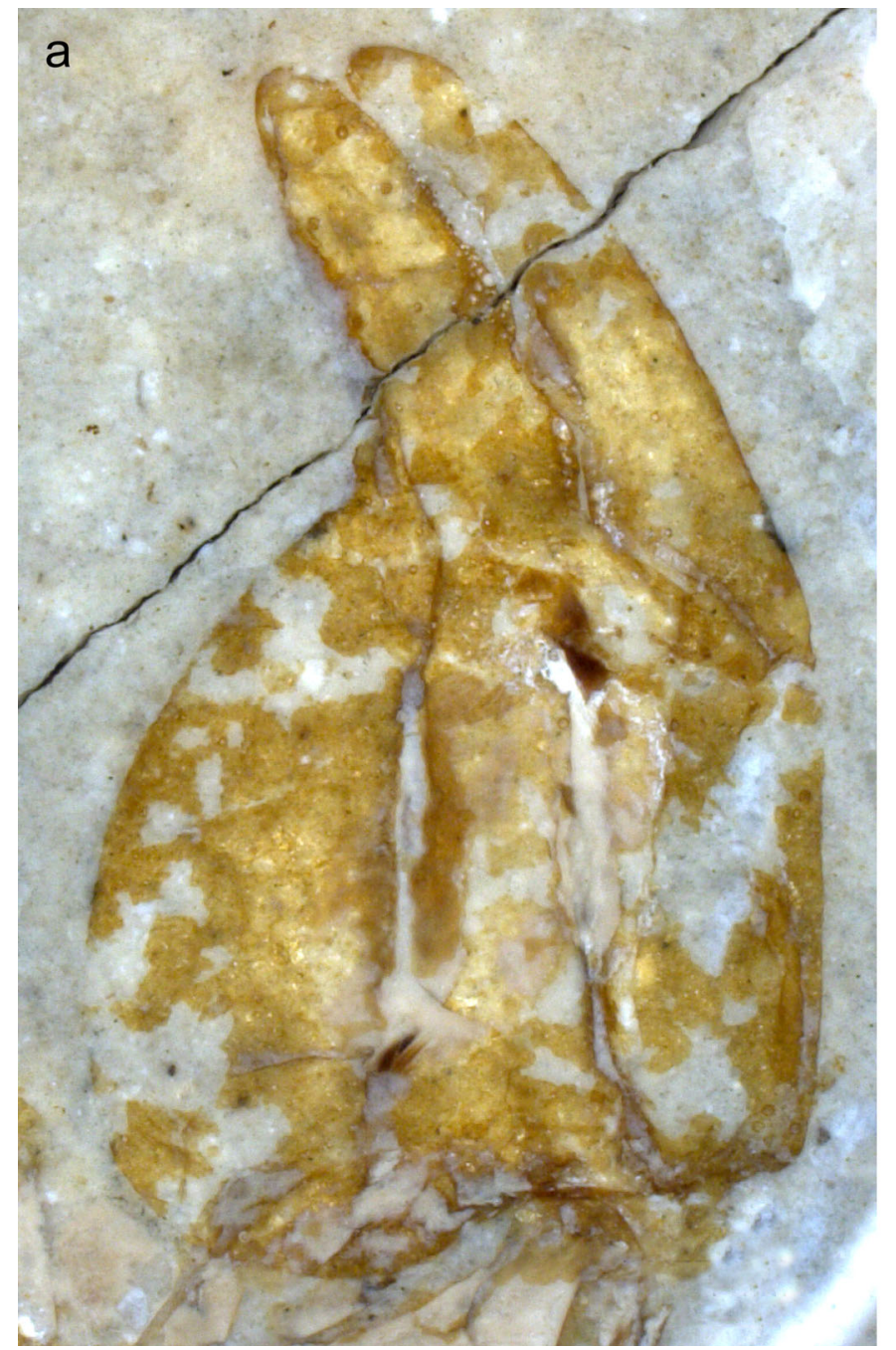

dominant structures of the scorpion. The carapace is $4.8 \mathrm{~mm}$ long and $2.1 \mathrm{~mm}$ on the anterior width and $4.8 \mathrm{~mm}$ on the posterior width. In the middle region, the mesosoma is $6.6 \mathrm{~mm}$ wide on average. These measurements give an impression of the scorpion size. More detailed measurements are listed in Table 1.

The carapace of the scorpion is sub-quadrangular with a strong convex emargination at the anterior margin. The cuticle of the anterior region is darker than the rest, which may be because of the carapace thickness. Lateral eyes would at best be preserved on the left carapace half, but their number cannot be determined with certainty. As mentioned before, the median eyes are not preserved, but their former position is marked by a heard-like notch on the carapace surface. The median eyes are situated in the middle of the carapace. Posteriorly, a deep furrow separates the carapace in two halves.

At the anterior to the frontal carapace margin, a small (1.3-mm-long and 0.8 -mm-wide) laminated structure is

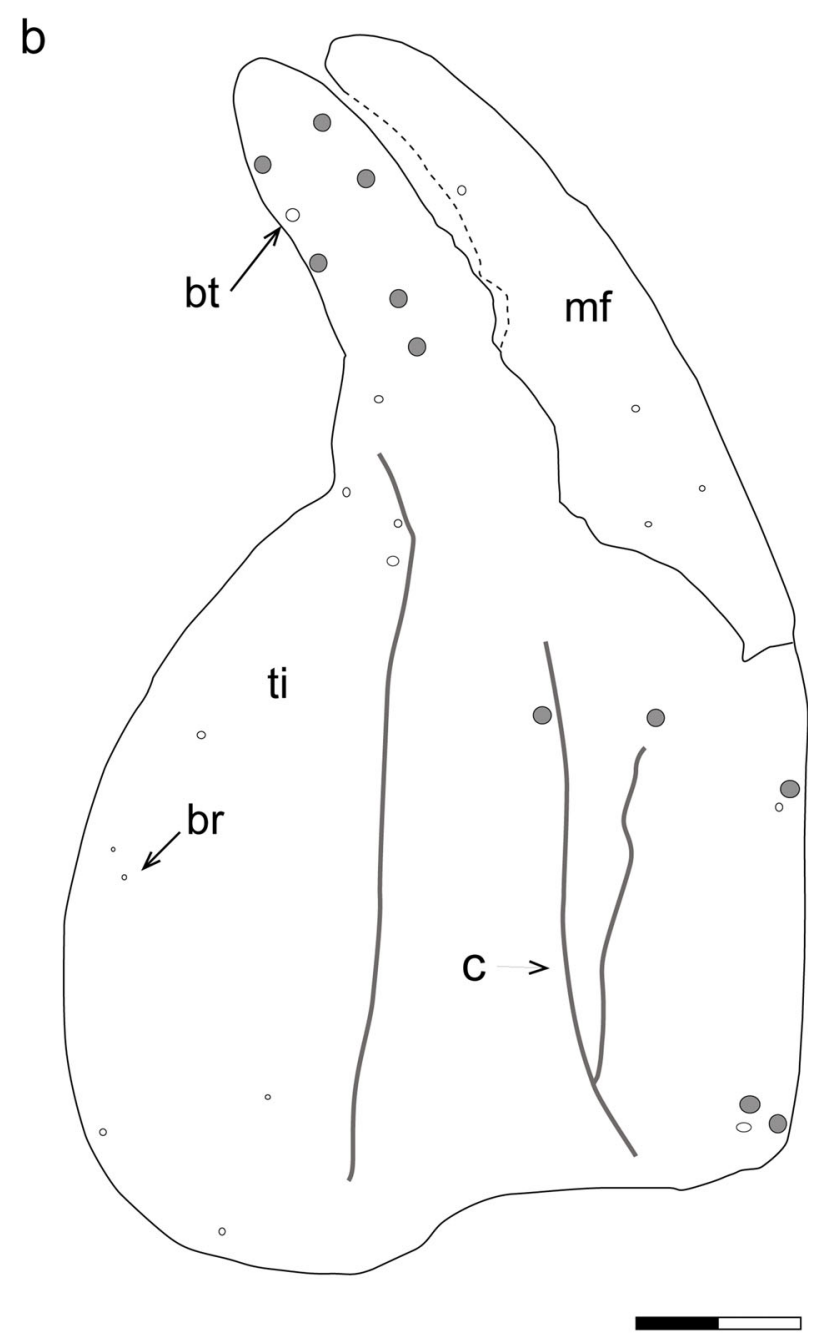

Fig. 2 a, b Right pedipalp chela of Eoeuscorpius ceratoi gen. et sp. nov. br bristles, bt bothria, $c$ carina, $m f$ moveable finger, $t i$ tibia. Scale $1 \mathrm{~mm}$ 
exposed (Fig. 1b shaded area, Fig. 3). About 36 laminae are within the oval structure, with an average thickness of $0.02 \mathrm{~mm}$. This structure is interpreted as exposed muscle fibrils.

Although the chelicerae are normally best seen from the ventral side, in the specimen described herein the tibia and tarsus of the chelicerae are also exposed dorsally (Fig. 1a, b). As in most scorpions, the chelicerae are very small ( $2 \mathrm{~mm}$ long/1.3 mm wide for the complete structure). Parts of the more basal segments (e.g., the coxa) are also preserved, but unfortunately not in detail. The tibia is produced into the fixed finger. The inner ventral margin is equipped with a bristlecomb (Fig. 4a, b). On both the fixed and moveable finger (tibia and tarsus), tooth denticles are preserved. Roughly the teeth can be distinguished into distal, subdistal and median teeth (Vachon 1963; Sissom 1990). Again, the preservation is not detailed enough for further descriptions.

The pedipalps of the fossil are comparably short and stout. Especially the patella is considerably large. It has a roundish shape and on the cuticle surface three carinae from anterior to posterior. The two carinae on the right side form a $\mathrm{V}$ as they meet at the posterior region of the patella (Fig. 2a, b). On the cuticle surface of the patella,

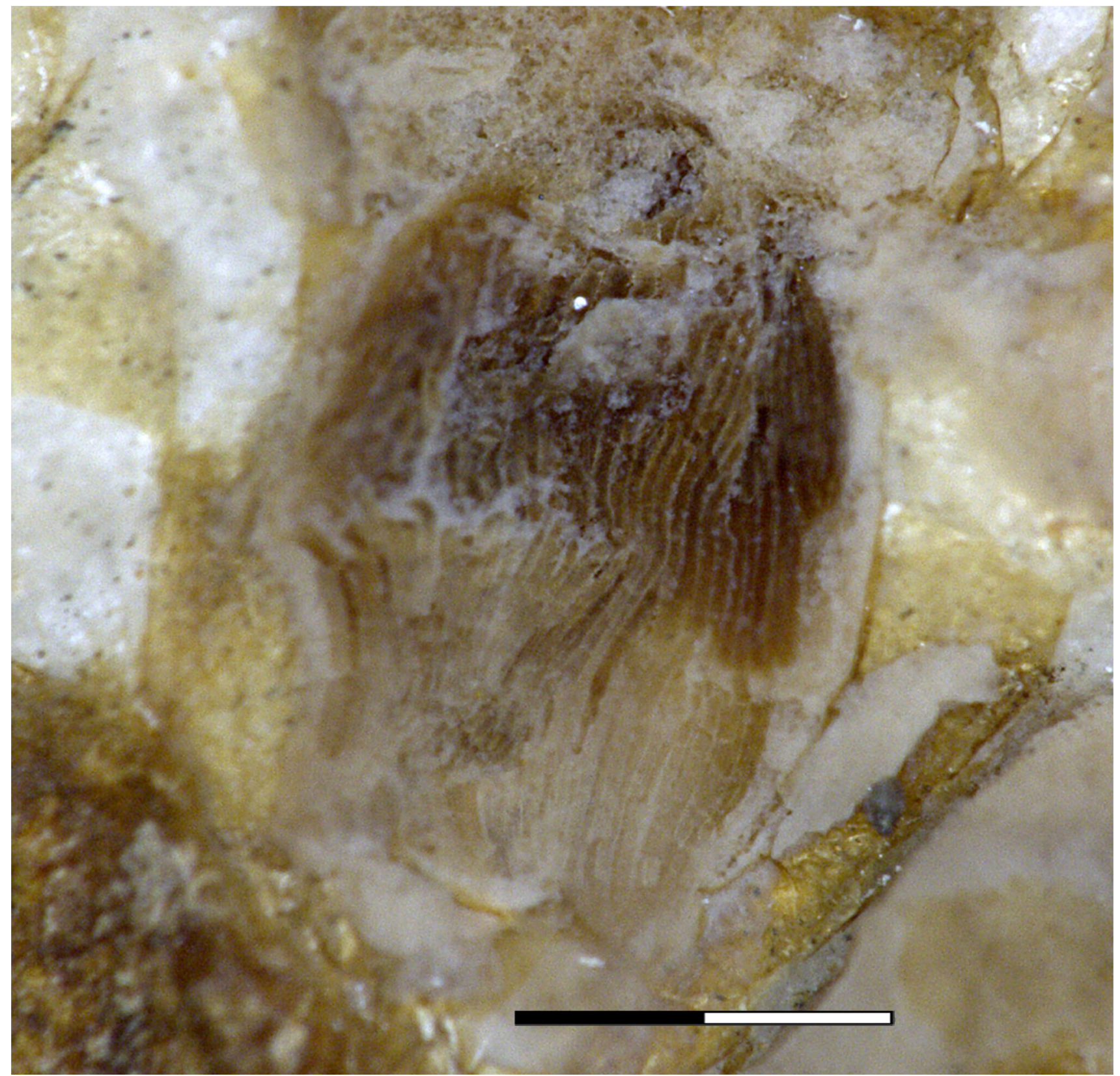

Fig. 3 Laminated structure on the scorpion surface above the carapace margin. Possible remains of muscle fibrils. Scale $0.5 \mathrm{~mm}$ 

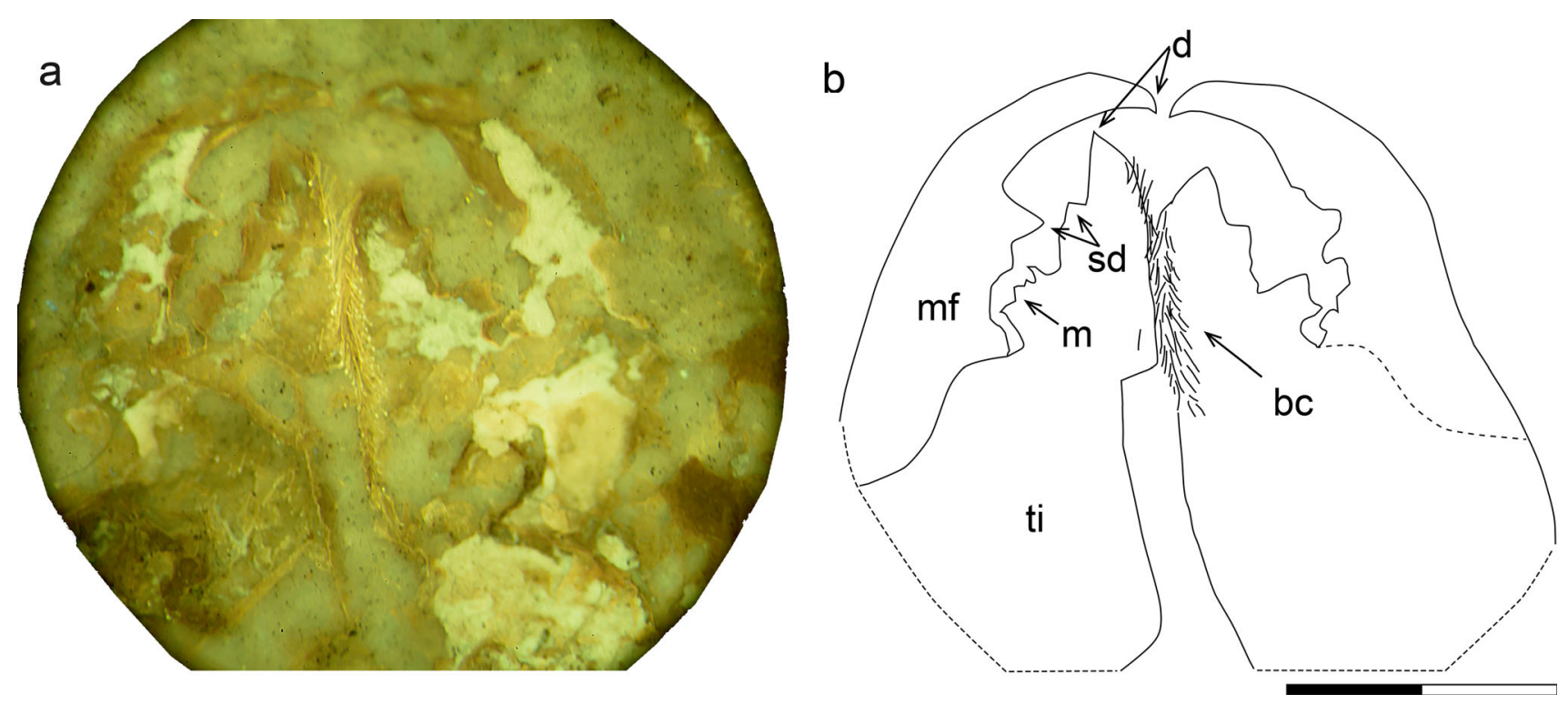

Fig. 4 a Left and right chelicera of Eoeuscorpius ceratoi gen. et sp. nov., fluorescence illumination. b Line drawing of chelicera. $b c$ bristlecomb, $d$ distal tooth, $s d$ subdistal tooth, $m$ median tooth, $m f$ moveable finger, $t i$ tibia. Scale $1 \mathrm{~mm}$

several insertion points show the former position of the bothria and other setae. These structures cannot be fully observed. However, some of the insertion points are larger than others. These larger insertion points (filled circles in Fig. 2b) are most certainly the remains of bothria. The trichobothrial pattern can be observed on the doral side on the pedipalps. Three bothria (internal, dorsal, external) are preserved on the femur. On the patella, one dorsal and one internal bothria is preserved, as well as four external bothria. The internal bothria is partially displaced; four to six bothria are preserved on the dorso-external aspect of the chela hand, and five bothria are on the chela fixed finger.

Though incompletely preserved, the overall impression of the legs is that they were slender compared to the robust pedipalps. The tibia of the walking legs is broader than the preceding and following leg segments. The basitarsus and tarsus are shorter than the more basal segments. Tarsal claws are not preserved.

The mesosoma consists of seven segments, covered by mesosomal tergites. Tergites are rectangular in shape, with rounded edges. A carina proceeds close beneath the anterior margin of each mesosomal tergite, except on tergite VII (Fig. 1a, b). The width of the dorsal mesosomal tergites varies from 5.8 to $6.5 \mathrm{~mm}$ from tergite I to tergite VII. There is more variation in the length (measured from anterior to posterior). The first and second mesosomal tergites are only about $0.9 \mathrm{~mm}$ long; the third measures $1.4 \mathrm{~mm}$. The fourth mesosomal tergite is about $1.6 \mathrm{~mm}$ long. The following mesosomal tergites show similar lengths of 2.3 and $2.4 \mathrm{~mm}$. The seventh mesosomal tergite differs from the others in being trapezoid. It is roughly
$3 \mathrm{~mm}$ long. The anterior part is $5 \mathrm{~mm}$ wide, whereas the posterior part measures only $3.3 \mathrm{~mm}$.

Two additional ventral plates of mesosomal segments five and six are preserved. Their shape and size are comparable to their dorsal pendants.

The metasoma of the fossil scorpion consists of five segments, plus the telson (Fig. 1a, b). With the exception of segment $\mathrm{V}$, tail segments are approximately of the same size. Segment $\mathrm{V}$ is one and half times longer than the preceding ones. On each metasomal segment, two longitudinal carinae are preserved. The cuticle surface is densely covered with granules. The telson aculeus is partly covered by segment $\mathrm{V}$, because it is bent backwards (as in life position). The tip of the aculeus is broken.

\section{Discussion}

The scorpion is one individual of the minor fauna (Guisberti et al. 2014), which is the animal non-fish fauna and comprises inter alia a few arthropod genera. The scorpion is originally regarded as terrestrial, so it was deposited allochthonously. As the depositional environment was not far away from the coastline, it was most probable washed in from nearby land.

A definitive phylogenetic position of the scorpion is difficult to determine because of the incompleteness of the specimen. According to the observed characters-the general morphology, shape of pedipalp segments (i.e., femur, patella and chela), presence of a small apophysis on the internal aspect of the patella, and the same numbers and positions of some trichobothria-the specimen is 
unquestionably a representative of the Chactoidea and can be assigned temporarily to the extant family ?Euscorpiidae (see Lourenço 2015). However, because of the incompleteness of the specimen and in particular because of the geological horizon (Eocene), the specimen is assigned provisionally to a new genus.

Euscorpiidae were hitherto only known from extant representatives. The family comprises 31 species, belonging to four genera (Lourenço 2015). Eoeuscorpius ceratoi gen. et sp. nov. would be the fifth genus (comprising one species), probably giving the family Euscorpiidae a fossil record that goes back more than 49 million years.

Acknowledgements Before all others, we thank Mr. Massimo Cerato (Verona) for access to his fossil scorpion. We also sincerely thank Roberto Zorzin (Verona) for friendly communication, for information on the fossil and helpful comments on the manuscript. Additionally, we thank Torsten Wappler (Bonn) for technical help with pictures and Georg Oleschinski (Bonn) for the high-quality photographs. Additionally, we would like to thank the reviewers (Jason Dunlop and Andrea Rossi) and editors (Joachim Haug and Mike Reich) for helpful comments and constructive suggestions, which helped to improve our manuscript.

\section{References}

Briggs, D.E.G., and S. McMahon. 2016. The role of experiments in investigating the taphonomy of exceptional preservation. Palaeontology 59: 1-11.

Carnevale, G., A.F. Bannikov, G. Marramà, J.C. Tyler, R. Zorzin, and G. Carnevale. 2014. The Pesciara-Monte Postale Fossil-Lagerstätte: 2. Fishes and other vertebrates. In The Bolca FossilLagerstätten: A window into the Eocene World, eds. C.A. Papazzoni, L. Guisberti, G. Roghi, D. Bassi, and R. Zorzin, 37-64. Milano. (Supplemento al Bollettino della Società Paleontologica Italiana 53(1) = Rendiconti della Società Paleontologica Italiana 4$)$.

Cerato, M. 2011. Cerato. I pescatori del Tempo. San Giovanni Ilarione (VR): Grafica Alpone.

Dunlop, J.A. 2010. Geological history and phylogeny of Chelicerata. Arthropod Structure and Development 29: 124-142.

Dunlop, J.A., D. Penney, O.E. Teltie, and L.I. Anderson. 2008. How many species of fossil arachnids are there? The Journal of Arachnology 36: 267-272.

Dunlop, J. A., D. Penney, D. Jekel. 2017. A summary list of fossil spiders and their relatives. In World Spider Catalog. Natural History Museum Bern, online at http://wsc.nmbe.ch, version 18.0, accessed on [15.03.2017].

Guisberti, L., M. Fornasiero, and R. Zorzin. 2014. The PesciaraMonte Postale Fossil-Lagerstätte: 4. The "minor fauna" of the laminites. In The Bolca Fossil-Lagerstätten: A window into the
Eocene World, eds. C.A. Papazzoni, L. Guisberti, G. Carnevale, G. Roghi, D. Bassi, and R. Zorzin, 73-88. Milano. (Supplemento al Bollettino della Società Paleontologica Italiana 53(1) = Rendiconti della Società Paleontologica Italiana 4).

Lourenço, W.R. 2003. The first scorpion fossil from the Cretaceous amber of France. New implications for the phylogeny of Chactoidea. Comptes Rendus Palevol (Académie des Sciences) Paris 2: 213-219.

Lourenço, W. R. 2009. A synopsis on amber scorpions, with special reference to the Baltic fauna. Denisia (n. ser.) 86: 131-136.

Lourenço, W.R. 2014. A new species of scorpion from Chiapas amber, Mexico (Scorpiones: Buthidae). Revista Ibérica de Aracnologia 24: 59-63.

Lourenço, W.R. 2015. Scorpion diversity and distribution; past and present patterns. In Scorpion venoms, toxinology, eds. P. Gopalakrishnakone, L.D. Possani, E. Schwartz, R.C. Rodriguez, and de la Vega, 3-23. Heidelberg: Springer + Business Media Dordrecht.

Lourenço, W.R. 2016. A Synopsis on amber scorpions with special reference to Burmite species; an extraordinary development of our knowledge in only 20 years. Zookeys 600: 75-87.

Papazzoni, C.A., G. Carnevale, E. Fornaciari, L. Guisberti, and E. Trevisani. 2014. The Pesciara-Monte Postale Fossil-Lagerstätte: 1. Biostratigraphy, sedimentology and depositional model. In The Bolca Fossil-Lagerstätten: A window into the Eocene World, eds. C.A. Papazzoni, L. Guisberti, G. Carnevale, G. Roghi, D. Bassi, and R. Zorzin, 29-36. Milano. (Supplemento al Bollettino della Società Paleontologica Italiana 53(1) = Rendiconti della Società Paleontologica Italiana 4).

Schwark, L., A. Ferretti, C.A. Papazzoni, and E. Trevisani. 2009. Organic geochemistry and paleoenvironment of the Early Eocene "Pesciara di Bolca" Konservat-Lagerstätte, Italy. Palaeogeography, Palaeoclimatology, Palaeoecology 273: 272-285.

Sissom, W.D. 1990. Systematics, biogeography and paleontology. In Biology of scorpions, ed. G.A. Polis, 64-160. Stanford: Stanford University.

Tang, C.M. 2001. Monte bolca: an eocene fishbowl. In Exceptional fossil preservation, eds. D.J. Bottjer, W. Etter, J.W. Hagadorn, and C.M. Tang, 365-378. New York: Columbia University.

Vachon, M. 1963. De l'utilité, en systématique, d'une nomenclature des dents des chélicères chez les Scorpions. Bulletin du Muséum national d'Histoire naturelle (2e sér.) 35(2): 161-166.

Vachon, M. 1974. Etude des caractères utilisés pour classer les familles et les genres de Scorpions (Arachnides). 1. La trichobothriotaxie en arachnologie. Sigles trichobothriaux et types de trichobothriotaxie chez les Scorpions. Bulletin du Muséum national d'Histoire naturelle (3e sér.) 140: 857-958.

Wilde, V., G. Roghi, and E. Martinetto. 2014. The Pesciara-Monte Postale Fossil-Lagerstätte: 3. Flora. In The Bolca FossilLagerstätten: A window into the Eocene World, eds. C.A. Papazzoni, L. Guisberti, G. Carnevale, G. Roghi, D. Bassi, and R. Zorzin, 65-72. Milano. (Supplemento al Bollettino della Società Paleontologica Italiana 53(1) = Rendiconti della Società Paleontologica Italiana 4). 